\title{
South African consumer sentiment towards marketing
}

\author{
Christo Boshoff" and Alwyn P. du Plessis \\ Department of Business Economics, Vista University, Private Bag X613, Port Elizabeth 6000, Republic of South Africa
}

Received 20 March 1991; accepted 18 February 1992

\begin{abstract}
Generally the marketing literature suggests that the key to a firm's survival and growth is its satisfaction of consumer needs. This philosophy is embodied in the so-called marketing concept. In order to determine to what exsend South African firms succeed in achieving consumer satisfaction, this study investigated empirically, the way in which consumers perceive marketing and marketing related practices. The results of a survey involving 3000 respondents suggest that consumers are fairly dissatisfied with the marketing fratemity and its activities. The 'Index of Consumer Sentiment Towards Marketing' is $-16,262$ with a theoretical maximum and minimum of +280 and -280 , respectively. The only positive index for an individual marketing mix element is that for retailing and the lowest index is that for pricing. The results show that marketers are not perceived as being successful in satisfying market requirements.
\end{abstract}

In hierdie arikel word die resultate van 'n empiriese opname onder verbruikers na bepaalde bemarkingspraktyke, beskryf. Vir die doel van die opname is vraelyste aan 3000 respondente gestuur. Die belangrikheid om vas te stel hoe tevrede die verbruiker met die bemarkingskonsep is, het as grondslag vir die ondersoek gedien. Die bevindings dui daarop dat verbruikers in die algemeen redelik ontevrede met Suid-Afrikannse bemarkingspraktyke is. Ten einde die meting van houdings te bewerkstellig, word van 'n sogenaamde 'Index of Consumer Sentiment Towards Marketing' gebruik gemaak. Dié indeks, gebaseer op die empiriese resultate, kom op $-16,262$ te staan, met 'n teoretiese maksimum en minimum van onderskeidelik +280 en -280 . Op ' $n$ individuele grondslag is die indeks slegs ten opsigte van die kleinhandel positief, terwyl die indeks vir pryse die grootste negatiewe waande het. Die bevindinge won dat bemarkers kennis moet neem van die negatiewe houdings by verbruikers ten opsigte van bermarkingsprakryke.

*To whom correspondence should be addressed.

\section{Introduction}

The origin of the marketing concept can be traced back to 1913 (Berry, 1988) and has since, supposedly, been the guiding philosophy of modern-day marketing thought. It holds that the key to achieving the firm's objectives is to establish what the needs and wants of target markets are, and to deliver the desired satisfactions more effectively and efficiently than competitors (Kotler, 1988: 17). The marketing concept is based on three fundamental principles (McCarthy \& Perreault, 1987), namely:

1. a customer orientation;

2. a co-ordinated, integrated effort to satisfy consumer needs; and

3. profit rather than sales as an objective.

The marketing concept can thus be described as a marketfocused, customer-oriented, co-ordinated marketing effort aimed at generating customer satisfaction which is essential in order to realize the firm's objectives (Kotler, 1988: 18). A business firm is therefore unlikely to be profitable over the long term if it fails to satisfy consumer needs and wants. Survival in a capitalistic economy thus becomes near impossible (McGee \& Spiro, 1988: 42).

Proponents of the marketing concept believe that adherence to it will be to the advantage of both the firm and consumers (Fram, 1965: 26). Others have criticised it (Bell \& Emory, 1971) and acceptance has not been universal (McCarthy \& Perreault, 1987: 31; McNamara, 1972). A study conducted in the early 1970s, for instance, found that despite a fairly positive inclination towards the concept and beliefs that both firms and consumers benefit from it, top management and marketing executives of very few firms succeeded in implementing the concept and operationalising it in terms of the daily activities of a business firm (Barksdale \& Darden, 1971: 36).
Reasons why some firms fail to accept and implement the marketing concept and become truely customer orientated are (Webster, 1988: 29):

- A poor understanding of the concept.

- Inability to reconcile the (sometimes) conflicting demands of short and long term sales on the one hand and profitability objectives on the other.

- Evaluation of management performance in terms of shortsighted financially-based criteria, rather than market-based criteria.

- Management's inability to view customer needs and requirements as a priority above the interests of all other claimants on the firm's resources.

Reluctance to accept and implement the marketing concept has had two important consequences. Firstly, consumers elected to vote with their money by patronising firms who offered superior customer satisfaction at reasonable prices. It is for this reason that many believe that American firms have lost their domination of world markets to Asian countries (Webster, 1988). Secondly, consumers began to organise themselves to protect their rights as consumers. The latter action, which became known as the consumer movement or consumerism, attempts to protect individuals against practices which could harm their rights as consumers (Day \& Aaker, 1970: 13) by striving to realise the objectives of more extensive consumer information, improved consumer education and more effective protection as buyers.

The mere fact that consumers have found it necessary to insist on these rights may be a serious allegation against business firms in general and marketing in particular (Becker, 1972; Buskirk \& Rothe, 1970). Peter Drucker (in Kotler, 1972) has described consumerism as '...the shame of the total marketing concept...' while a Business Week aricle 
(quoted in Bell \& Emory, 1971), stated that '...consumerism can be defined as the bankruptcy of what business schools have been calling the "marketing concept".

Although such comment may be exaggerated and overcritical, it does cast the commitment of business firms to satisfying consumer needs, in doubt. Such comment also emphasizes the need to analyse consumer perceptions of marketing practice and activities.

\section{Prevlous research}

Studies which investigated consumer dissatisfaction, can be divided into two groups (Warland, Herrmann \& Willits, 1975). One group of studies attempted to describe the personality characteristics of consumers who were dissatisfied with various business and marketing practices. Barksdale \& Darden (1972), for instance, investigated consumer perceptions of business and marketing practice. Somewhat disconcerting for the marketing fratemity, respondents in the Barksdale \& Darden survey did not believe that business firms implement the marketing concept. Slighty more than $52 \%$ of the respondents believed that manufacturers were more interested in making profits than serving customers. Almost half of the respondents believed that manufacturers did not employ the philosophy that the consumer is always right (Barksdale \& Darden, 1972).

Besides business philosophy, Barksdale \& Darden (1972) addressed five additional issues namely Product Quality, Advertising, Other Marketing Activities, Consumer Responsibilities and Government Regulation. The study was repeated in 1973 and 1975, with the addition of a seventh issue, namely Prices and Price Control, in an attempt to detect possible trends over a five-year period. The three studies (conducted during 1972, 1973 and 1975) found, similarly to the study of Barksdale \& Darden (1972), that consumers simply did not believe that business firms regarded consumer satisfaction as a primary objective (Barksdale, Darden \& Perreault, 1976). In addition, the sceptical and cynical perception of the commitment of business to the marketing concept did not change over the five-year period. Respondents did feel that firms attempted to manufacture products that would suit their needs but expressed the view that manufacturers often prefered product style changes rather than making genuine improvements to product quality. Respondents were particularly critical of advertising in all three surveys reported by Barksdale et. al. (1976). The majority of respondents disagreed that most product advertising was believable, that advertising information pertaining to product quality and performance was reliable and that advertising presented a true picture of the actual product itself. With regard to consumerism, about $75 \%$ of respondents felt that exploitation of the consumer deserved more attention, but about $45 \%$ in all three surveys (1972, 1973, 1975) expressed the view that firms were more sensitive to customer complaints than in the past.

The second group of studies attempted to describe the consumers who were dissatisfied and who complained about the treatment they received from firms. These studies also analysed the things these consumers complained about. The first group of sudies thus used the attitude of consumers as dependent variable, and to the second group, behaviour was the dependent variable.

The studies which included the actual behaviour of dis satisfied consumers (the second group), yielded inconsisten and often conflicting findings. The fairly negative consumer perceptions reported by Barksdale \& Darden (1972) and Barksdale et. al. (1976), for instance, were largely echoed by Hustad \& Pessemier (1973) in their attempt to profile dissatisfied consumers. They found that younger women of relatively higher intellectual, social and economic levels felt particularly negative towards business practices. Wartand et. al. (1975), on the other hand, found that '...a large number of consumers in the country appear relatively satisfied with the market system...' and '...a majority of those interviewed did not report getting upset'. Warland et. al. (1975) conceded, however, that many consumers who do get upset do nothing about it or take actions which are not overt. A possible reason for these inconsistencies is inadequate distinction between the dissatisfied consumers who actually complain and those who do not do anything about it.

\section{Measuring consumer sentiment}

The preceding literature review may raise the question of how South African business firms fare in their attempts to satisfy consumer needs. At least one international survey, covering 24 countries, found South Africa to be the second worst with regard to service delivery. Few can argue away the regularity with which letters of complaint appear in newspaper and magazine letter columns. Headings and headlines such as 'Ripped off by P E garage "sharks"; 'Sloppy film service'; 'Ripped off? How to complain' have become commonplace. ${ }^{2}$ Indeed, the phrase 'ripped off' has become a household word.

This study attempts to address the question of how effective business firms are in their endeavours to satisfy consumer needs, by measuring consumer sentiment towards marketing practice and activities. The assessment ought to assist marketers in their forecasting and planning endeavours in particular. Other potential advantages are that it may (Gaski \& Etzel, 1986):

- sensitise marketers to consumer perceptions;

- identify the nature of the public relations task facing marketing; and

- indicate to consumers that marketing cares enough about the public to elicit their opinion and in this way enhance its public image.

In addition, Krauss (1987: 73) suggests that such measures are normally leading indicators to market share changes. The information can be used to improve profitability, particularly by employing customer satisfaction ratings as a basis for employee remuneration. It can also be used to evaluate the effectiveness of management and the marketing function, in particular.

\section{Objectives of this study}

The primary objective of this study, was to measure general consumer sentiment towards marketing practices, by means 
of a quantified index. Secondary objectives included an investigation to establish to what extent this sentiment was influenced by demographic variables.

\section{Methodology}

\section{Sample}

In order to measure consumer sentiment towards marketing in a South African context, the population was regarded as all white consumers of both genders, permanently resident in the country. The address list of the South African Broadcasting Corporation's television licence holders was used as sampling frame. A systematic random sample of 3000 respondents was selected after a random start. Questionnaires were mailed to each, accompanied by a covering letter and a self-addressed, stamped envelope. A response rate of $24.17 \%$ was realised. The demographic composition of the respondent group is shown in Table 1.

Although no comparison with a national profile is attempted, distribution among the various classifications is either fairly equal or as in the case of areas of residence (urban versus rural), as could be expected. The only possible exception is gender, where almost two thirds of respondents were males. If one considers that the television licence of a household is likely to be registered in the name of the head of the household, which in South Africa is likely to be male, the high incidence of male respondents is understandable.

\section{Measuring instrument}

The questionnaire which served as measuring instrument in this study was originally developed by Gaski \& Etzel (1986). It measures consumer sentiment towards marketing via attitudes towards the four major elements of marketing practice. These elements are product, price, promotion and personal selling/retailing. Statements were generated with the intention to measure the respondent's perceptions of each of the four elements, linked to a 5-point Likert-type scale. By marking a 1 , respondents indicated strong agreement with the statement while a 5 signalled strong disagreement.

Besides ensuring comprehensibility through extensive pre-testing, the instrument was subjected, by Gaski \& Etzel (1986), to purification through reliability analysis. Cronbach's alpha was utilised for this purpose. The alpha values indicated a high degree of reliability (Gaski \& Etzel, 1986). A principal axis common factor analysis with an oblique rotation, confirmed the reliability and discriminant validity of the four scale categories of the questionnaire. The convergent validation for the entire measure or index (as opposed to the four categories) was also confirmed, leading Gaski \& Etzel to conclude:

'...the validation evidence ... is considered promising and a likely strength of the measure relative to others that have been presented in the literature' (1986: 76).

\section{Some validity and reliability considerations in this study}

As pointed out earlier Gaski \& Etzel (1986) did establish the validity and reliability of their measuring instrument. Two of their measures were repeated in this study. The
Table 1 Demographic composition of sample

\begin{tabular}{|c|c|c|}
\hline \multirow{2}{*}{$\begin{array}{l}\text { Demographic variable } \\
\text { Gender }\end{array}$} & \multicolumn{2}{|c|}{ Number Percentage } \\
\hline & & \\
\hline \multirow[t]{2}{*}{$\begin{array}{l}\text { Male } \\
\text { Female }\end{array}$} & $\begin{array}{l}462 \\
263 \\
\end{array}$ & $\begin{array}{l}63.72 \\
36.28 \\
\end{array}$ \\
\hline & 725 & 100.00 \\
\hline \multicolumn{3}{|l|}{ Age } \\
\hline \multirow[t]{2}{*}{$\begin{array}{l}15-19 \\
20-24 \\
25-34 \\
35-44 \\
45-54 \\
55-64 \\
65-74 \\
75+\end{array}$} & $\begin{array}{r}1 \\
20 \\
121 \\
175 \\
139 \\
123 \\
111 \\
35 \\
\end{array}$ & $\begin{array}{r}0.14 \\
2.76 \\
16.69 \\
24.14 \\
19.17 \\
16.96 \\
15.31 \\
4.83\end{array}$ \\
\hline & 725 & 100.00 \\
\hline \multicolumn{3}{|l|}{ Marital status } \\
\hline \multirow[t]{2}{*}{$\begin{array}{l}\text { Married } \\
\text { Never married } \\
\text { Widow/widower } \\
\text { Divorced } \\
\text { Living together }\end{array}$} & $\begin{array}{r}553 \\
50 \\
65 \\
49 \\
8\end{array}$ & $\begin{array}{r}76.28 \\
6.90 \\
8.97 \\
6.75 \\
1.10\end{array}$ \\
\hline & 725 & 100.00 \\
\hline \multicolumn{3}{|l|}{ Educational qualifications } \\
\hline \multirow[t]{2}{*}{$\begin{array}{l}\text { Sid. } 8 \text { and lower } \\
\text { Std. } 9 \text { or eguivalent qualification } \\
\text { Std } 10 \text { or equivalent qualification } \\
\text { Matric plus diploma(s) } \\
\text { Matric plus degree(s) }\end{array}$} & $\begin{array}{r}83 \\
35 \\
218 \\
223 \\
166\end{array}$ & $\begin{array}{r}11.45 \\
4.83 \\
30.07 \\
30.76 \\
22.89\end{array}$ \\
\hline & 725 & 100.00 \\
\hline \multicolumn{3}{|l|}{ Home language } \\
\hline \multirow[t]{2}{*}{$\begin{array}{l}\text { Afrikaans } \\
\text { English } \\
\text { European language }\end{array}$} & $\begin{array}{r}365 \\
346 \\
14\end{array}$ & $\begin{array}{r}50.35 \\
47.72 \\
1.93\end{array}$ \\
\hline & 725 & 100.00 \\
\hline \multicolumn{3}{|l|}{ Position in labour market } \\
\hline \multirow[t]{2}{*}{$\begin{array}{l}\text { Employer } \\
\text { Own employee } \\
\text { Employee } \\
\text { Unemployed } \\
\text { Student } \\
\text { Housewife } \\
\text { Pensioner } \\
\text { Not fit for work }\end{array}$} & $\begin{array}{r}109 \\
47 \\
350 \\
2 \\
6 \\
56 \\
154 \\
1 \\
\end{array}$ & $\begin{array}{r}15.03 \\
6.48 \\
48.28 \\
0.28 \\
0.83 \\
7.72 \\
21.24 \\
0.14 \\
\end{array}$ \\
\hline & 725 & 100.00 \\
\hline \multicolumn{3}{|l|}{ Ares of residence } \\
\hline \multirow[t]{2}{*}{$\begin{array}{l}\text { Urban } \\
\text { Rural }\end{array}$} & $\begin{array}{l}527 \\
198 \\
\end{array}$ & $\begin{array}{l}72.69 \\
27.31 \\
\end{array}$ \\
\hline & 725 & 100.00 \\
\hline
\end{tabular}

reliability of each category of the measure was assessed by calculating an alpha coefficient for each category as well as an item-to-total correlation. Shown in Table 2 is the alpha coefficient of each category. All alpha coefficients are satisfactory and compare well with those reported by Gaski and Etzel (1986). The high alpha coefficients demonstrate internal consistency or reliability, which can be regarded as indirect evidence of validity, as a necessary but not sufficient condition.

In Table 3 the item-to-total correlations of this study are compared to those reported by Gaski and Etzel (1986). Not only do the item-to-total correlations correspond favourably with those of Gaski and Etzel (1986), but similarly high alpha coefficients are reported. Relatively high alpha coeffients demonstrate internal consistency or reliability which is regarded as a necessary but not a sufficient condition for 
Table 2 Alpha values

\begin{tabular}{lll}
\hline $\begin{array}{l}\text { Questionnaire } \\
\text { calegory }\end{array}$ & $\begin{array}{l}\text { This } \\
\text { study }\end{array}$ & $\begin{array}{l}\text { Gaski and } \\
\text { Eezel (1986) }\end{array}$ \\
\hline Product & 0.846 & 0.817 \\
Price & 0.716 & 0.772 \\
Advertising & 0.794 & 0.761 \\
Resailing & 0.755 & 0.783 \\
\hline
\end{tabular}

Table 3 Item-to-total correlation

\begin{tabular}{|c|c|c|}
\hline & $\begin{array}{l}\text { This } \\
\text { study }\end{array}$ & $\begin{array}{l}\text { Gaakj \& } \\
\text { Euzel (1986) }\end{array}$ \\
\hline \multicolumn{3}{|l|}{ Product } \\
\hline Item 1 & 0.735 & 0.491 \\
\hline Ilem 2 & 0.726 & 0.543 \\
\hline Item 3 & 0.633 & 0.570 \\
\hline Item 4 & 0.723 & 0.480 \\
\hline Item 5 & 0.780 & 0.642 \\
\hline Item 6 & 0.746 & 0.639 \\
\hline hem 7 & 0.701 & 0.533 \\
\hline \multicolumn{3}{|l|}{ Price } \\
\hline Ilem 1 & 0.549 & 0.514 \\
\hline ltem 2 & 0.542 & 0.477 \\
\hline Item 3 & 0.684 & 0.500 \\
\hline Item 4 & 0.593 & 0.403 \\
\hline Ilem 5 & 0.496 & 0.333 \\
\hline Item 6 & 0.723 & 0.646 \\
\hline Item 7 & 0.699 & 0.630 \\
\hline \multicolumn{3}{|l|}{ Adven } \\
\hline Item 1 & 0.549 & 0.359 \\
\hline Item 2 & 0.687 & 0.544 \\
\hline Item 3 & 0.697 & 0.567 \\
\hline Item 4 & 0.730 & 0.515 \\
\hline Item 5 & 0.690 & 0.469 \\
\hline Item 6 & 0.592 & 0.314 \\
\hline Item 7 & 0.731 & 0.600 \\
\hline \multicolumn{3}{|l|}{ Retail } \\
\hline Item 1 & 0.723 & 0.604 \\
\hline Item 2 & 0.691 & 0.591 \\
\hline Item 3 & 0.769 & 0.622 \\
\hline hem 4 & 0.446 & 0.410 \\
\hline Ilem 5 & 0.308 & 0.133 \\
\hline Ihem 6 & 0.729 & 0.587 \\
\hline Leen 7 & 0.733 & 0.631 \\
\hline
\end{tabular}

validity (Churchill, 1976: 251-252; Gaski \& Etzel, 1986: 74).

In addition, a principal factor analysis (oblique rotation) was conducted. In Table 4 is revealed that all items except items 15 and 26 loaded heavily on a different factor as expected, which confirms the reliability and discriminant validity of the measuring instrument.
Table 4 Sorted rotated factor loadings

\begin{tabular}{|c|c|c|c|c|c|}
\hline & $\begin{array}{l}\text { Factor } 1 \\
\text { Product }\end{array}$ & $\begin{array}{l}\text { Factor } 2 \\
\text { Adven }\end{array}$ & $\begin{array}{l}\text { Factor } 3 \\
\text { Retail }\end{array}$ & $\begin{array}{l}\text { Factor } 4 \\
\text { Price }\end{array}$ & Communalitiea \\
\hline V5 & 0.770 & 0.022 & 0.019 & -0.037 & 0.4661 \\
\hline V4 & 0.714 & 0.042 & -0.070 & -0.038 & 0.4490 \\
\hline V6 & 0.644 & 0.138 & 0.022 & 0.022 & 0.4050 \\
\hline v3 & 0.598 & 0.054 & -0.076 & -0.058 & 0.4026 \\
\hline V1 & 0.589 & -0.143 & 0.165 & 0.121 & 0.1669 \\
\hline $\mathbf{v} 2$ & 0.582 & -0.112 & 0.183 & 0.077 & 0.5604 \\
\hline v7 & 0.530 & -0.081 & 0.132 & 0.159 & 0.4935 \\
\hline V21 & 0.069 & 0.686 & 0.081 & -0.059 & 0.1786 \\
\hline V17 & 0.130 & 0.672 & -0.065 & -0.060 & 0.3134 \\
\hline V18 & -0.023 & 0.645 & 0.041 & -0.033 & 0.5233 \\
\hline V16 & -0.021 & 0.622 & 0.051 & -0.005 & 0.5830 \\
\hline V20 & 0.062 & 0.490 & 0.009 & 0.100 & 0.1346 \\
\hline V19 & -0.076 & 0.487 & 0.184 & 0.102 & 0.5277 \\
\hline V26 & 0.012 & 0.310 & -0.078 & 0.283 & 0.3317 \\
\hline V24 & -0.003 & -0.014 & 0.763 & 0.026 & 0.4812 \\
\hline v22 & 0.017 & -0.090 & 0.719 & 0.054 & 0.5923 \\
\hline V28 & 0.064 & 0.047 & 0.680 & 0.065 & 0.5284 \\
\hline $\mathbf{V}_{23}$ & 0.095 & 0.235 & 0.504 & -0.146 & 0.2747 \\
\hline v27 & 0.073 & 0.265 & 0.460 & -0.021 & 0.2756 \\
\hline V25 & 0.091 & -0.036 & 0.326 & 0.031 & 0.1319 \\
\hline V15 & -0.033 & 0.233 & 0.304 & 0.077 & 0.3899 \\
\hline V13 & -0.035 & -0.097 & 0.077 & 0.768 & 0.4755 \\
\hline V14 & 0.105 & -0.065 & 0.028 & 0.672 & 0.4073 \\
\hline V10 & -0.045 & -0.103 & 0.120 & 0.645 & 0.3016 \\
\hline v11 & 0.017 & 0.028 & 0.020 & 0.390 & 0.5033 \\
\hline V8 & 0.104 & 0.226 & -0.160 & 0.374 & 0.3691 \\
\hline v9 & 0.038 & 0.265 & -0.179 & 0.373 & 0.2209 \\
\hline V12 & 0.092 & 0.094 & -0.005 & 0.281 & 0.3492 \\
\hline
\end{tabular}

Although these tests are incomplete to deduce reliabilty and validity, they do not suggest the contrary, and compare favourably with those reported by Gaski \& Etzel (1986).

\section{An Index of consumer sentiment toward marketing}

Responses to all questions were scored from +2 to -2 with the most favourable answer (that is, strongly agree with a positive statement and strongly disagree with a negative statement) receiving the highest score. Scores for each item in each category was importance-weighted, scored on a 5point scale of extremely important (5) to not at all important (1). These responses were then fitted to the following formula, suggested by Gaski \& Etzel (1986) to measure consumers' sentiment toward marketing practices.

The measure of overall consumer sentiment toward marketing is then

$$
\sum_{j=1}^{n} w_{j} \sum_{i=1}^{m} x_{i j}
$$

with

$x_{i j}=$ scale item response $i$ in category $j$,

$w_{j}=$ importance weight for the marketing mix category $j$,

$m=$ number of items in category (7), and

$n$ = number of categories (4). 
Table 5 Index of consumer sentiment: .: Marketing mix elements and total

\begin{tabular}{lrrrr}
\hline $\begin{array}{l}\text { Marketing mix } \\
\text { elementhotal }\end{array}$ & Index & \multicolumn{2}{c}{ Renge } & S.D \\
& & Minimum Maximum & \\
\hline Product & -2.719 & -70 & +70 & 9.04 \\
Price & -8.470 & -70 & +70 & 9.07 \\
Adverising & -6.434 & -70 & +70 & 21.39 \\
Retuiling & +1.361 & -70 & +70 & 10.82 \\
Total & -16.262 & -280 & +280 & 34.36 \\
\hline
\end{tabular}

This represents an attitude score for an individual respondent. The mean score across all respondents can then be calculated and converted to an index number as a measure of general sentiment.

In Table 5 is shown that the overall index of consumer sentiment toward marketing practices is slightly in the unfavourable range $(-16.262)$. The individual marketing mix element with the lowest index is that of pricing practices $(-8.470)$ and the highest index that of retailing $(+1.361)$. The low index for pricing may be due to the prominence given to many price rises in the media. Increases in the prices of bread, milk and petrol, for instance, are normally headline news. The positive index for retailing, on the other hand, may be attributed to the success of particularly large retail chains of convincing consumers that they are 'fighting for the consumer'.

A second objective of this study was to establish to what extent consumers' attitudes towards marketing (as measured by the overall index) are influenced by demographic considerations. The overall index and the index for individual marketing mix elements served as dependent variables in five separate regression analyses (one for the overall index and one for each marketing mix element). The demographic characteristics which served as independent variables in each of these regression analyses were: gender, age, home language, area of residence (urban versus rural), marital status, level of education and position in the labour market.

In Table $6^{3}$ is shown that consumers' attitude toward marketing are primarily influenced by age.

Table 6 Influence of demographic variables on the marketing index ${ }^{3}$

\begin{tabular}{llll}
\hline Parameter & Coefficient & T-value & $\mathrm{p}>\mathrm{l}$ \\
\hline Intercept & -6.350 & -1.82 & 0.0694 \\
Age & -2.504 & -3.05 & $0.0024^{\circ}$ \\
\hline
\end{tabular}

$\mathrm{a}=\mathrm{p}<0.01$

According to Table 6, older respondents are significantly $(p<0.01)$ more dissatisfied with marketing and marketing practices than younger respondents. In other words, the older consumers are, the more likely they are to be dissatisfied with the marketing fraternity.
In Table 6 is also revealed, by implication, that the demographic variables gender, home language, area of residence (urban versus rural), marital status position in the labour market and level of education, do not have a significant influence on how respondents perceive marketing and marketing practices.

In Table 7 , on the other hand, is revealed that three demographic variables have a significant influence on how respondents perceive product-related considerations. These are gender, home language and the position of respondents in the labour market. In the case of gender, females rate product items significantly $(p<0.05)$ lower than males. English-speaking respondents rate products and product quality items significantly $(p<0.01)$ lower than their Afrikaans-speaking counterparts. Employees (those who work for others, in this case position in labour market 2), perceive product considerations significantly $(p<0.01)$ worse than other respondents.

In Table 7 is by implication revealed that biographical variables such as age, educational qualification, marital status and area of residence (rural versus urban) have no significant influence on perceptions regarding product related issues.

In Table 8 is shown that area of residence (urban versus rural), position in the labour market and marital status are the demographic variables which have a significant influence on price perceptions. Consumers living in urban areas are significantly $(p<0.05)$ more dissatisfied with pricing practices than those living in rural areas. Contrary, consumers who are active in the labour market as employees (those who work for fixed salaries) are more dissatisfied with pricing than those who are, for instance, employers or self-employed. Similarly, those who are married or live together are more dissatisfied about the prices of products and services than others. In Table 8 is also by implication, suggested that gender, age, educational qualification and home language have no significant influence on how respondents perceive price considerations.

In Table 9 is shown that both age and level of education have a significant $(p<0.01)$ influence on how respondents perceive advertising and advertising practices. The relationship between age and advertising perceptions is negative. In other words, the older respondents are, the more unhappy

Table 7 Influence of biographic variables on product perceptions

\begin{tabular}{lcrc}
\hline \multicolumn{4}{c}{ Dependent variable: Product index } \\
\hline Independent variables & Coefficient & T-Value & $\mathrm{p}>\mathrm{t}$ \\
\hline Intercept & -2.396 & -6.05 & 0.0001 \\
Gender & 0.923 & 2.47 & $0.0139^{\circ}$ \\
Home language & 1.298 & 3.85 & $0.0001^{\circ}$ \\
Position in labour marke 1 & -0.671 & -1.00 & 0.3195 \\
Position in labour marke 2 & -1.431 & -2.69 & $0.0074^{\circ}$ \\
Position in labour marke 3 & 0.533 & 0.83 & 0.4074 \\
\hline$a=p<0.01$ & & & \\
$b=p<0.05$ & & & \\
\hline
\end{tabular}


Table 8 Influence of demographic variables on price perceptions

\begin{tabular}{lcrc}
\hline \multicolumn{4}{c}{ Dependent variable: Price index } \\
\hline Independent variables & Coefficient & T-Value & p > t \\
\hline Intercept & -6.850 & -11.42 & 0.0001 \\
Area & -0.893 & -2.35 & $0.0190^{b}$ \\
Marital stums - married/ive together & -1.238 & -2.16 & $0.0313^{\circ}$ \\
Marital status - widow/divorced & +0.585 & +0.80 & 0.4246 \\
Position in labour market 1 & +0.002 & 0.00 & 0.9970 \\
Position in labour market 2 & -1.102 & -2.07 & $0.0388^{\circ}$ \\
Position in labour market 3 & +0.233 & +0.35 & 0.7256 \\
\hline b $=\mathrm{p}<0.05$ & & & \\
\hline
\end{tabular}

Table 9 Influence of demographic variables on advertising perceptions

\begin{tabular}{lccc}
\hline \multicolumn{4}{c}{ Dependent variable: Advertising index } \\
\hline Independent variables & Coefficient & T-Value & $p>t$ \\
\hline Intercept & -0.565 & -0.17 & 0.8662 \\
Age & -2.797 & -5.88 & $0.0001^{*}$ \\
Level of education & +1.698 & +2.65 & $0.0082^{*}$ \\
\hline$=p<0.01$ & & & \\
\hline
\end{tabular}

they are with advertising practices. The relationship between level of education and advertising perceptions is positive, implying that better qualified respondents are more satisfied with advertising and advertising practices than the less qualified respondents.

In Table 9 is also by implication, revealed that gender, marital status, home language, position in labour market and area of residence, have no significant influence on how respondents perceive advertising. When the retailing index was used as dependent variable, it emerged that neither of the demographic variables used as independent variables in this study, has any influence on retailing perceptions.

\section{Implications for marketing management}

The overall negative index of consumer sentiment towards marketing ought to be a source of concern to the entire marketing fratemity. Relatively older consumers are particularly dissatisfied with current marketing practices. The concern of older consumers for the future spending power of their money is probably an important consideration.

The only aspect of marketing which seems to meet with consumers' approval is that of retailing/selling, implying that consumers regard in-store service and merchandising to be at an acceptable standard.

The low index for pricing suggests than consumers view pricing as unfair and unreasonable. Marketers must accept that consumers are becoming increasingly critical and sophisticated and will have to make some effort to justify price increases if this negative perception is to be changed.
Consumers who work for fixed incomes (employees) ex. pressed particular concern about pricing, as inflation is like. ly to have a negative impact on their spending power.

Poor product quality has proved, in at least one study (Moss \& Richardson, 1985: 6) to be '... consistently and massively the greatest single source of customer complaint'. It is therefore not surprising that products and product quality also retumed a negative index score. It implies that consumers perceive the products they buy to be of poor quality, which do not perform as expected or are defective in some way. Marketing should refrain from viewing the problem as a production concem as the responsibility for converting consumer expectations to need satisfying pro. ducts remains with marketing. In addition, marketers must realise that quality is likely to be the most important consumer trend of the 1990s (Rabin, 1983), which offers unique opportunities to establish a competitive advantage.

Advertising's negative index seem to stem from poor perceptions among two market segments namely, older consumers and those who are relatively less well educated. Older consumers are typically more conservative and may not approve of modern advertising techniques such as the use of rap music. Lesser educated consumers may be suspicious and may regard advertising claims as mostly falsa, having the intention to deceive rather than to inform consumers. To change this negative perception advertisers will have to pay particular attention to this criticism and take into account the needs of these two market segments.

\section{Summary}

This study records the dissatisfaction of consumers with the marketing fraternity's activities which implies a failure to adhere to the basic principles of the marketing concept.

Table 10 indicates which potential market segments are relatively speaking, more dissatisfied with various marketing considerations. These segments will probably demand particular attention if the image of marketing and the marketing fratemity is to be improved.

\section{Notes}

1. The survey was conducted by Sales Performance Strategies, a consultancy firm, on behalf of the European business publi. cation Excel and Export Times.

2. (i) Eastern Province Herald, 8 November 1989, 14.

(ii) Eastern Province Herarld, 3 October 1989, 6.

(iii) You magazine, 21 December 1989, 8-9.

Table 10 Summary: Who are more dissatisfied with what?

\begin{tabular}{|c|c|}
\hline Overall index & Older consumers \\
\hline Products & $\begin{array}{l}\text { English-speaking consumers } \\
\text { Females }\end{array}$ \\
\hline \multirow[t]{3}{*}{ Price } & $\begin{array}{l}\text { Employees } \\
\text { Urban consumers }\end{array}$ \\
\hline & Employees \\
\hline & Married/live together \\
\hline \multirow[t]{2}{*}{ Advertising } & Older consumers \\
\hline & Less well qualified respondents \\
\hline Retalling & None \\
\hline
\end{tabular}


3. Only those demographic variables which exert a significant influence on the relevant index are kept in the model and reported in the tables.

\section{References}

Barksdale, H.C. \& Darden, B. 1971. Marketers' attitudes towards the marketing concept. J. Marketing, Vol. 35, October: 29-36. Barksdale, H.C. \& Darden, W.R. 1972. Consumer atuitudes towards marketing and consumerism.J. Marketing, Vol. 36, October: 28-35.

Barksdale, H.C., Darden, W.R. \& Perreault, W.D., Jr. 1976. Changes in consumer attitudes toward marketing, consumerism and government regulation: 1971-1975. J. Consumer Affairs, Vol. 10, Winter: 117-139.

Becker, B.W. 1972. Consumerism: A challenge or a threat? J. Retailing, Vol. 48, No. 2, Summer: 16-28.

Bell, M.L. \& Emory, C.W. 1971. The faltering marketing concept. J. Marketing. Vol. 35, October: 37-42.

Berry, L.L. 1988. The marketing concept revisited. Marketing News, 18 July: 26 \& 28.

Buskirk, R.H. \& Rothe, J.T. 1970. Consumerism - An interpretation. J. Marketing, Vol. 34, October: 61-65.

Churchill, G.A., Jr. 1976. Marketing research: Methodological foundations. Hinsdale, Illinois: Dryden.

Day, G.S. \& Aaker, D.A. 1970. A guide to consumerism. J. Marketing, Vol. 34, July: 12-19.

Fram, E.H. 1965. Application of the marketing concept to retailing. J. Retailing, Summer: 19-26.

Gaski, J.F. \& Etzel, M.J. 1986. The index of consumer sentiment toward marketing. J. Marketing, Vol. 50, July: 71-81.
Hustad, T.P. \& Pessemier, R.A. 1973. Will the real consumer activist please stand up: An examination of consumess' opinions about marketing practices. J. Marketing Research, August: 319-324.

Kotler, P. 1972. What consumerism means for marketers. Harvard Bus. Rev., May-June: 48-57.

Kotler, P. 1988. Marketing management: Analysis, planning, implemention and control. Sixth Ed. Englewood Cliffs, New Jersey: Prentice-Hall.

Krauss, C.J. 1987. Customer satisfaction: A bottom line performance indicator. In: Suprenant, C. (ed.) Add value to your service: the key to success. American Marketing Association, Proceedings Series, 73-79.

McCarthy, EJ. \& Perreault, W.D., Jr. 1987. Basic marketing. Ninth Ed. Homewood, Illinois: Irwin.

Mc Gee, L.W. \& Spiro, R.L. 1988. The marketing concept in perspective. Bus. Horizons, Vol. 31, No. 3, May-June: 40-45.

McNamara, C.P. 1972. The present status of the marketing concept. J. Marketing, January: 50-57.

Moss, C.D. \& Richardson, B. 1985. Customer satisfaction - The key to successful and legally unfettered trading. European $J$. Marketing, Vol. 19, No. 6: 5-11.

Rabin, J.H. 1983. Accent is on quality in consumer goods and services this decade. Marketing News, March: 13.

Warland, R.H., Herrmann, R.O. \& Willits, J. 1975. Dissatisfied consumers: Who gets upset and who takes action. J. Consumer Affairs, Vol. 9: 148-163.

Webster, F.E., Jr. 1988. The rediscovery of the marketing concept. Bus. Horizons, Vol. 31, No. 3, May-June: 29-39. 